\title{
Educating the next generation of teachers: 21st century skills, research and ICT competencies through PBL
}

DOI: https://doi.org/10.21897/25394185.1483

\author{
Educando a la nueva generación de profesores: ABP para \\ desarrollar habilidades para el siglo 21,TIC e investigación
}

Rosa María Guilleumas García, roguiga@utp.edu.co

Universidad Tecnológica de Pereira, Colombia.

\begin{abstract}
Living in the 21st century demands from all citizens, but particularly from teachers, the development of specific skills to face the challenges of a society in which information and communication are the key to successful fulfillment of most work and life needs. According to the Partnership for 21 st century skills (2011), these skills include learning and innovation skills (creativity and innovation, critical thinking and problem solving, and communication and collaboration), Information, Media and Technology skills and Life and Career skills (flexibility and adaptability, Initiative and SelfDirection, Social and Cross Cultural Skills, Productivity and Accountability, Leadership and Responsibility).At the same time, the improvement and modernization of educational practices in the English as foreign language (henceforth EFL) field require reflective teachers with strong research skills that enable them to observe and analyze their educational contexts in order to propose creative and viable alternatives to traditional methodologies. Project-based learning (hereafter PBL) provides an ideal framework to guide teachers in development towards the acquisition of the aforementioned abilities in an engaging and motivating way and gives them a first-hand experience on the usefulness of this methodology for enhancing language and research competencies as well as 21 st century skills.
\end{abstract}

Keywords: 21 st century skills, PBL, ICT competencies, teaching foreign languages, research in the classroom.

\section{Resumen}

El siglo XXI exige de todos los ciudadanos, pero particularmente de los docentes, habilidades específicas con las que afrontar los desafíos de una sociedad en la que la información y la comunicación son la clave para el éxito en la vida y el trabajo. Según el Consorcio para las Habilidades del Siglo XXI esto implica desarrollar competencias de aprendizaje e innovación, habilidades para el manejo de la información, los medios y la tecnología, y habilidades para la vida y el trabajo. Al mismo tiempo, la mejora y la modernización de las prácticas educativas en el campo de la enseñanza del inglés como lengua extrajera requiere docentes reflexivos, con fuertes competencias en investigación que les permitan observar y analizar críticamente los contextos educativos y proponer alternativas viables y creativas a las metodologías de enseñanza tradicionales. El aprendizaje basado en proyectos (ABP) proporciona un marco adecuado para lograr que los docentes en formación desarrollen las habilidades anteriormente mencionadas de forma motivadora y les proporciona una experiencia real sobre la utilidad de esta metodología para incrementar las competencias linguísticas y de investigación así como las habilidades del siglo XXI.

Palabras claves: Habilidades del siglo 21, ABP, enseñanza de una segunda lengua, competencias en TIC, investigación en el aula. 


\section{Introduction}

The world has changed significantly in the last 30 years, particularly in the field of technology, with inventions and devices continuously replaced by something faster, more efficient, smaller or simply newer, at the point that some of those inventions were already discontinued before we had time to experience them or had mastered their possibilities.

The technological race has not stopped but rather has sped up and, unlike developments in other fields, which take years in spreading, new technologies are adopted readily by big segments of population, for which they become quickly something not only natural but absolutely essential.

Internet and the development of mobile devices have been the most important catalysts for these changes, since they have made possible an almost general access to information, social media and all kinds of contents and services, for people of all economic and educational levels.

We have reached a point in which most of our daily life activities are somehow mediated by technology: from communicating with friends, family and colleagues through mobile applications like whatsapp, snapchat, or other similar to working and buying services or products. We use phone apps for calling a taxi, buying lunch, or watching television and we use internet in order to find information for solving everyday problems. This is the society in which teachers must perform their job; a hyperconnected society in which students are used to having access to technology and information at any time and place.

Society expects much from teachers, who must be able to communicate efficiently in order to connect with the new generation of students; must investigate and apply new methodologies for teaching and must be able to use technologies reflectively and appropriately to enhance learning. Teacher training programs should reflect those needs and prepare teachers with the competencies they need nowadays to face the challenges of our profession.

Learning based on collaborative projects mediated by Information and Communication Technologies (hereinafter ICT) provides the opportunity to learn with active methodologies, in an interdisciplinary way and starting from the centers of interest of the students. Besides, this approach gives future teachers not only the occasion to develop their critical thinking and their investigative, communicative, collaborative and creative skills, but also a first-hand experience on the transformative role that the appropriate use of ICT can have in the process of learning a foreign language.

Through the following pages we will explore in more depth the elements mentioned: 21 st century skills, teachers' researching role and the possibilities afforded by PBL for integrating all of them in an engaging learning process.

\section{21st century skills}

The last 50 years have brought many changes to society in general and to the labour market in particular, which has undergone a deep transformation. From 2007, the world has lived in a deep financial crisis, considered by economists as the worst since the Great Depression of the 1930s, with thousands of companies going bankrupt and huge numbers of people losing their jobs as a consequence. In Spain, for instance, the number of unemployed people went from $8.8 \%$ at the beginning of 2007 (one of the lowest numbers in the Spanish economic history) to $17.1 \%$ in $2017^{1}$.

Many of those people faced great difficulties for finding new jobs, not only because with less companies, there were less available employments, but also because little by little, the world economies had started to change and were turning from economies based on the production and manufacturing of goods into economies based on knowledge and services.

We were entering the «information society», «- a society where a majority of workers is involved 
in producing, handling and distributing information or codified knowledge (...), in contrast to what we were used to, workers producing goods, tangible products» (OECD, 1996, p.13). That is how, little by little, computer literacy (knowing how to use effectively a computer and its applications) and access to network facilities started to become more important than literacy in the traditional sense (OECD, 1996) and learning of both turned essential for citizens and workers of the information society.

These changes have had consequences on people's lives. Although there are still people who keep the same job for long periods of time, it is by no means common any longer that a person keeps the same employment throughout life. According to Rapacon (2016, para.1), «career change is the new normal of working».

New skills are demanded by these changes, skills that were identified and described by the Partnership for 21st century learning ${ }^{2}$ as the basic abilities and knowledge necessary «to succeed in work, life and citizenship» (Partnership for 21st century learning, 2007, para.1) in the information society.

The core of 21 st century skills is formed by knowledge about what are considered the classic subjects of education: the so-called 3Rs (reading, (w)riting and (a)rithmetics), mathematics, science, history and geography, world languages, arts, etc. However, this organization emphasizes the need of helping future citizens develop also a much higher level of knowledge referred to:

- Environmental literacy: awareness, knowledge and attitudes that facilitate and promote participation in civic actions aimed at protecting the environment. It includes our role and responsibility as consumers.

- Civic literacy: the knowledge and attitudes that allow and promote participation in civic life to exert the rights and obligations of citizenship as well as the understanding of local and global implications of civic decisions

- Financial, Economic, Business and Entrepreneurial literacy: knowing how to make appropriate personal economic choices, understanding the role of economy in society and using entrepreneurial skills to enhance workplace productivity and career options.

- Health literacy: the knowledge and attitudes that allow to obtain, interpret and understand basic health information and services and use them to take responsible and appropriate actions towards health by means of taking preventive physical and mental health measures like proper nutrition, exercise, risk avoidance and stress reduction.

- Global awareness: conscious of a multicultural society in which people belonging to different cultures, religions and nationalities live and work together, the 21st century partnership encourages educational institutions and policy makers to promote the value of diversity as well as understanding of global issues and the ability to learn and work collaboratively with people from diverse origins and cultures in a spirit of respect and open dialogue.

Apart from this knowledge, the 21st century partnership recommends taking actions to integrate to the educational system the following elements: 1) Life and career skills like flexibility and adaptability, initiative and self-direction, social and cross cultural skills, productivity and accountability, and leadership and responsibility, 2) Information, media and technology skills, which consist of information literacy, media literacy and Information and Communication Technologies literacy, «the skills, strategies, social practices and dispositions required to use online information effectively to learn» (The Brainwaves Video Anthology, 2014, 1:47); and 3) Learning and innovation skills. Erika Andersen, in her article «How Google picks new employees» explains that this company, one of the most successful and innovative ones in the world, that «prides itself on coming up with new ideas and approaches on a daily basis» (Andersen, 2014, para.8), places expertise (so, knowledge) 
in the last position of the list of requirements they look for in their prospective employees. It is not that knowledge be not important, but they explain that the quality they actually value the most, is the extent to which their collaborators will be able to «pick up new things, to learn on the fly, to find information in disparate pieces of information and take the next step» (Andersen, 2014, p.8).

This ability for learning and innovation is materialized in four (4) subskills known as the 4Cs: Critical thinking, communication, collaboration, creativity.

\section{$1 \quad$ Critical thinking}

Defined simply as «the art of taking charge of our own mind» (Critical Thinking Foundation, 2015, p.1), it is described by educational psychologist Linda Elder, a prominent expert on the field, as «self-guided, self-disciplined thinking which attempts to reason at the highest level of quality in a fair minded way» (Critical Thinking Foundation, 2015, para. 12). The Critical Thinking Foundation, which Elder presides, explains that although we usually have reasons and motivations for our actions, it is unfrequent that we examine those reasons to see if they are rationally justified, and tend to act impulsively and uncritically in most fields: As consumers, buying things that we do not really need, as parents and teachers, discouraging children from thinking and being inconsistent in our actions and discourse, and as citizens, voting impulsively and uncritically without being well informed of the candidates' proposals and having analyzed them carefully (Critical Thinking Foundation, 2015).

The ability to look for information, analyse it, interpret it, separate opinion from fact, and distinguish reliable sources from those who do not deserve credit is part of this critical thinking skill. In an era in which the quantity of information and the facility for accessing it is enormous, we find that there are also many fake news, false rumors and hoaxes that intend to spread false information in order to influence public opinion in political campaigns, financial markets and many other topics like vaccinations or global warming which have important consequences on our lives.

Social media like Facebook, Twitter and instant messaging apps contribute signifficantly to the spreading of this false information, since many users simply pass it along without stopping to analyze it or consider its reliability. We are in the «post-truth» era, a period of history in which facts count less in influencing public opinion that emotion and personal belief. The problem is so serious that Facebook recently launched a strategy to stop disinformation in Spain and they will extend it to other countries as well.

One of the most curious experiments to raise awareness on the need for both critical thinking and internet and media literacy was the episode of the «Octopus that lives in the top of the trees.»

Some years ago, a plea for saving the «octopus paxarbolis» (also referred to as the Pacific Northwest Tree Octopus) was found in the internet. A search of information about such unusual creature revealed that there were articles, videos ${ }^{3}$ and even a frequently updated website ${ }^{4}$, which presented facts, frequent questions, sightings (some very recent!) and links to other sites about other endangered «animals of interest», like the «mountain walrus», «the Pacific Northwest Jumping Slugs» or the «rock nest monster». 


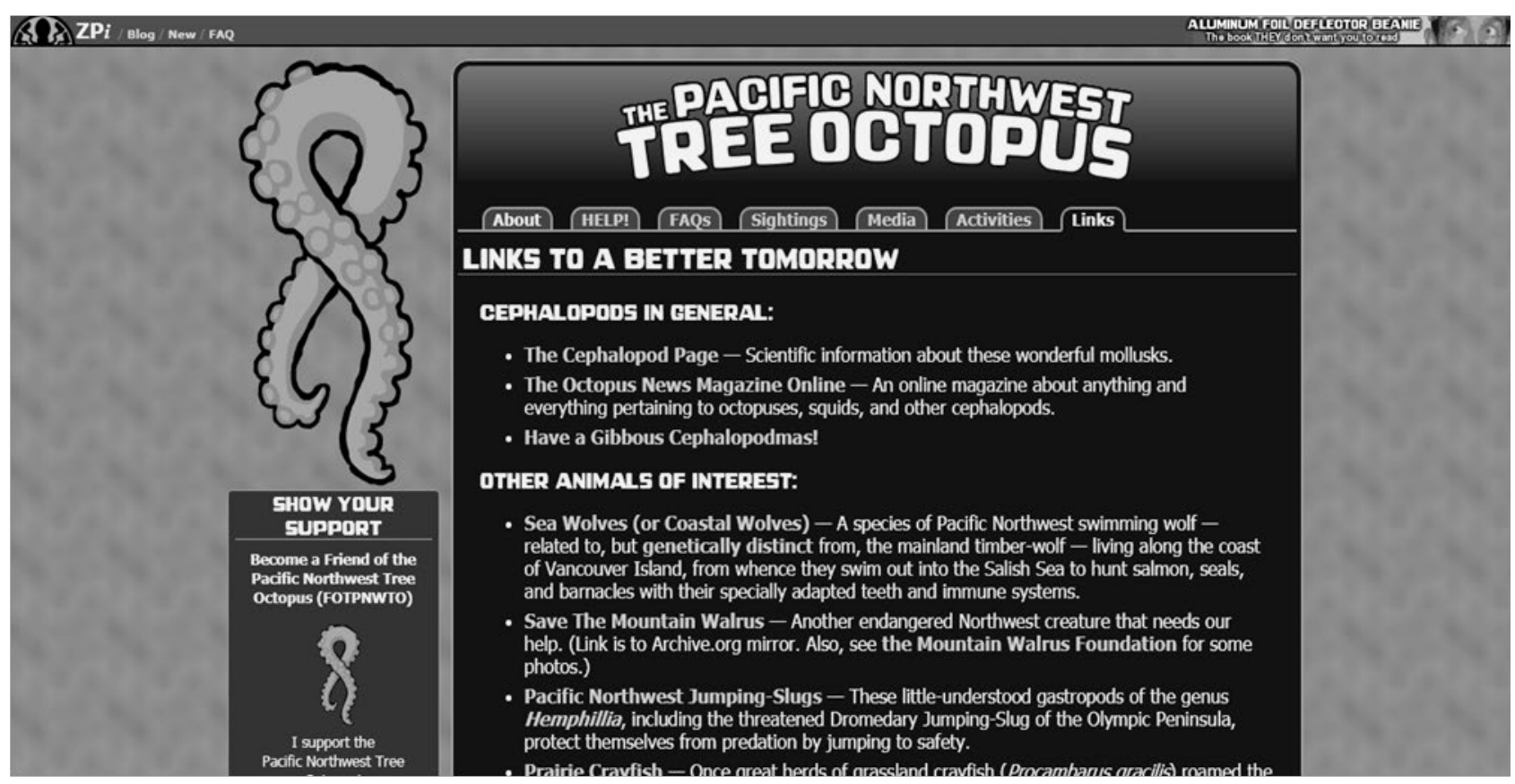

Figure 1: Screen capture of the Pacific Northwest tree octopus website.

All this evidence would surely make anyone doubt. However, the story was actually false. The website and the videos were part of a research study done by Dr. Donald Leu and his team at Connecticut University, in which students had to evaluate the credibility of a website. Regardless of the many clues inserted, as for instance references to other unlikely endangered species such as «the mountain walrus», «the jumping slug» or «the Sasquach» being the octopus' main predator, only $12 \%$ of the 48 participants in the study (12-13 year old students) considered it doubtful, even if they could not explain why (Trelease, 2013).

Although these web resources were created with the purpose of educating students in relation with the reliability (or lack of it) of the information they may find in the web, the results of the associated study constitute a very good example of how important not only digital literacy but also critical thinking are nowadays.

When we consider that the Oxford Dictionaries chose as Word of Year for 2016 the word posttruth - «an adjective defined as 'relating to or denoting circumstances in which objective facts are less influential in shaping public opinion than appeals to emotion and personal belief'» (Oxford University Press, 2017), we have to emphasize the importance of critically analyzing the information we receive from different sources, so we may counteract the actions of those playing at disinforming us with the purpose of influencing our behavior.

\section{Communication}

Communicative skills are among the most important abilities for anyone, since most life activities involve communicating with others. From professional settings to social and personal ones, lack of communication and misunderstandings are sources of difficulties and problems, while being able to accurately and appropriately present our ideas can help us achieve our goals.

For teachers, this skill becomes vital, since our job is based on communication. Speaking and writing clearly, precisely, adopting and respecting the conventions and demands of different media 
and avoiding misunderstanding is key for teachers. Connecting with our students and helping them to discover the world is, to a great extent, a matter of communication, where not only verbal cues are important but also non-verbal messages sent through facial expressions, gestures, body language, and tone of voice.

Blogs, forums, wikis, social media like Facebook, Twitter, Snapchat or Instagram among others, are the new scenarios for learning, where we can connect with peers and experts alike and learn at the same time that we make our contribution to other people's learning, what brings us to the 4th and last of the learning and innovation skills, Collaboration.

\section{Collaboration}

Collaborative work has supporters and detractors. As students, I am sure that most of us have had positive and negative experiences in team work, and usually people who has been successful working in isolation tend to regard collaborative work as a waste of time and a string of difficulties: from arranging times and places to meet to shouldering other partners' responsibilities.

However, team work and collaboration are essential nowadays. The most renowned companies in the world expect and demand from their employees the ability to work productively with others (remember the skills for life and career mentioned above?). Regardless of the job, you have to interact and collaborate with others and usually the best solutions and products are the result of a collective effort. In the case of teachers, even if you are the head of the group, you will have to collaborate with other colleagues in order to establish a coordinated plan for the subject, the course or the institution.

Internet tools have facilitated collaborating with others without the limitation of face to face encounters and have made possible what sociologist Pierre Levy considers humanity's greatest wealth: «collective intelligence», an intelligence that is created from the collaboration and contributions of many people. One of the best examples of collective intelligence is Wikipedia, which was created by the contributions of thousands of anonymous users, who took the time and the trouble to share their knowledge with others.

Collaborative learning is not only about learning, it also involves promoting confidence in the value of others' opinions, tolerance, leadership, assertiveness, self-confidence and proactivity, values that are among the most important results we want to achieve through education and that will help to build a better society. Finally, we come to the last of the $4 \mathrm{Cs}$, creativity.

\section{Creativity}

What is creativity? And why is suddenly so important? Sir Ken Robinson, a worldwide renowned educational expert defines creativity as «the process of having original ideas that have value» (2015, para.3) and explains that there are false ideas about creativity as for instance, that creativity is a gift only present in some people, that it is only referred to the arts, that it cannot be taught, or that it is based in self-expression. In contrast with these ideas, Robinson affirms that creativity is innate to human beings; that it is possible in all areas and that same as with other skills, we can educate and refine our creative ability, a skill that «is not just about having off-the-wall ideas and letting your imagination run free.»(Robinson, 2015, para. 6)

In one of his talks for TED Ed, he calls our attention to the fact that children starting school this year will be retiring in year 2074, and argues that if none of us knows how the world will be in 5 years time, much less can we predict what it will be by then. In his view, in order to respond to the challenges of a changing and uncertain future, marked by unpredictibility, education must accept the need to prepare the future generations so they can respond flexibly and appropriately to the 
circumstances, not only to the needs of the labour market. For that purpose, the capacity for thinking in alternative, original and creative ways is vital.

Coming to our field, language learning and teaching, it must be said that there are few things as creative as language use. As speakers, we exert our creativity continuously, starting at thinking and organizing our ideas, and then selecting our own way for expressing them. Language is both the tool and the product of creativity, allowing us to create beautiful products, able to awake all kind of emotions. Creativity is also at the base of language teaching since we need to respond creatively to the different circumstances that we observe in the class, create materials, activities and dynamics that can interest and motivate our students.

Many technologies that we use now in education were not iniatially educational technologies and it has been teachers' creativity what has made possible their use for supporting learning. Let's take for example QR codes. QR codes are the result of the evolution of the bar code. Used initially to store numeric information, the QR codes are able now to store all kind of information. Nobody would consider them an educational technology. However, the fact that they are able to store different types of information, from simple text to audio files, websites or even video, makes them a very interesting support for treasure hunts. We only need to create some QR codes containing the clues and tasks for the students, who, in turn, will simply use a cell phone with a camera, internet connection and a QR scanning app to access the information in the codes.

The cryptic characteristic of the QR codes and the possibility of using their cellphones, make the activity motivating for the students at the time that provide the opportunity of learning how to interact with this technological element. No need to mention that not all creative exercises have pedagogical usefulness. It is important that our creativity as teachers can be tempered with the educational purpose of the activity. Using technology just for the sake of it will not help us achieve better educational results.

\section{Teachers as researchers}

The second element of this paper has to do with the role of future teachers as researchers and as a consequence the need of developing research competencies as part of teachers' education. Why should we encourage teachers to do research? Don't they have enough with planning classes, teaching, preparing materials and the rest of responsibilities they have to fulfill with the students, the parents, and the institutions they work at?

I would say that, without undervaluing all what they must do both at schools and out of them, being involved in classroom research can help by providing three essential elements for any teacher: A sound foundation for making teaching decisions, a road for professional development, and an opportunity for impacting the field and gaining professional recognition, what in turn will open new professional opportunities and raise teachers' satisfaction.

\section{Research as a foundation for teaching}

As teachers, we know that each context, each group of students, and each student are different from others. They present their own challenges and demand flexible strategies that allow to adapt what happens in the classrooms to the specific needs encountered. At the same time, teachers are receiving information from many different sources about new approaches to teaching, methodological procedures, strategies and activities to be tried out in the classroom: CLIL, flipped classrooms, translanguaging, multiple intelligences, social emotional learning... and so forth. But, in the end, how do we take decisions in relation with what to do? With so much going on in the classroom, how can 
we be sure that our decisions are having a positive impact on students?

Furthermore, with great school failure and low student achievement rates (not only, but especially in students' English communicative competence), can we afford to continue taking teaching decisions on the grounds of hunches, intuition and superficial information? Consider the following. For the last 30 years, learning styles were all the rage. Teachers were encouraged to consider their students' learning styles as a fundamental element when planning class activities. Learning failure, we were said, was caused, among other reasons, by lack of understanding and use of students' preferred channels for learning, their dominant learning style.

Even the Colombian Ministry of Education demanded attention to learning styles in the 1290 Decree about Evaluation, and states that teachers must identify students' personal characteristics, interests, development rythms and learning styles to assess their progress. (Decreto 1290 de 2009, Artículo 3, p. 1). Since the purpose was to achieve learners' success, many teachers were actually doing great efforts at providing listening input for auditory learners, kinesthetic input for hands-on students, and visual resources for those preferring that input channel.

However, suddenly (well, maybe not so suddenly, since there have been studies in this sense since 2009) cognitive psychologists turned around and told us that learning styles were a neuromyth, and that there is no real evidence to support that providing input that matches a student's preferred learning style will improve their learning. However, although «their use in all forms of education has been thoroughly and repeatedly discredited in the research literature» (Newton, 2015, p. 1) there is still evidence of high rates of acceptance among teachers. According to Winter (2015, para.7) «a 2012 survey of teachers in the United Kingdom and Netherlands (...) revealed that the learning styles meshing hypothesis was the \#1 neuromyth, believed by 93 percent and 96 percent respectively. Another study of 938 teachers in five countries, conducted by Paul Howard-Jones in 2014 of 938 teachers, placed the figure at 96 percent.» This is actually sad, since teachers have multitude of tasks to perform and responsibilities to fulfill without adding to them that of following recommendations which have already been proved ineffective.

The question that remains is: Why is this neuromyth so persistent among teachers? Could it be because we got used to receiving methodological indications from «experts» and then applying their recommendations uncritically, without actually testing them in our classrooms? Research is considered by many as mainly an academic pursuit, a role reserved to scholars at universities, who explore and analyze reality to propose innovative (hopefully) and more efficient ways of dealing with a problem. Teachers are not expected to carry out research, but simply to apply, what other, brainier professors recommend them. As Robinson (2003, p.1) explains:

«Teachers are seen as consumers rather than producers of research. Researchers produce knowledge, and teachers consume it by applying in it in their schools and classrooms». Thus, the author highlights the existing gap between those who experience the problems in the real scenarios and those who actually do research about them.

Would it not be better if teachers, the real experts in what happens in their classrooms, engaged in doing their own research? That way they would be able to address the actual problems of their context and identify successful practices that would inform their own professional exercises instead of having to import solutions which were proposed for different contexts, and may or may not work on theirs. Research is the opportunity for leading educational change from within. As Hutchins, Huber and Ciccone (2011, p. 54) affirm, «faculty do their best work as teachers when they engage in inquiry... this inquiry produces its most fruitful and useful results when it is focused on learning and learners.» 


\section{Research as a road for professional development}

Continuing professional development is a must for any teacher and particularly any language teacher, since it guarantees that we remain competent in our profession, that our skills and knowledge are updated and therefore, that we can provide the best teaching to our students. Being involved in research takes us, in the first place, through a process of inquiry and deep exploration of a topic through the revision of different sources of information. Our readings, reflections and the connections established with our previous knowledge produce significant learning and contribute to keep us updated in the profession. Besides, getting involved in research means also stepping out of our confort zone and rediscovering the joy of learning about something we actually care about.

If what we are doing is action research, «the cycle of investigation, action planning, piloting of new practices and evaluation of outcomes» (Somekh, 2008, p. 4) may provide a kind of contextualized knowledge about our own teaching practices that can be more enriching than most professional development courses we may take, since it will talk directly to us about our own strengths and opportunities for improvement. As Somekh reminds us «The outcomes of action research are both practical and theoretical: The knowledge it generates has a direct and ongoing impact on changing practice for participants and on a wider audience through its publication» $(2008, \mathrm{p} .4)$. And this brings us to the third advantage of doing research: The publication of the results of our reseach and their public communication in congresses and academic conferences may help other teacher in similar circumstances and contexts, and also give us recognition in our field.

Students in teaching training programs complain frequently about having to read texts about teaching methodologies that come from contexts completely different from the ones we have to face here in Colombia. And it is true. Without belittling the importance and usefulness of research done abroad, it is true that it is difficult to find research done in our context and which coped with similar conditions to our own. The needs and decisions appropriate for a linguistically and culturally varied classroom of afluent EFL students in an immersion context, may not be equally appropriate for students sharing the same language in an English as a forein language context and belonging to a deprived community, and that is where research done by Colombian teachers for Colombian teachers may make a difference.

\section{Research as a means of achieving personal fulfilment}

Last but not least, research gives us the possibility of getting out of our comfort zone and rediscovering the joy of learning about something we actually care about. It also brings about the opportunity of attending and participating in events, to enjoy the pressure but also the satisfaction of sharing with other colleagues what we are doing and be an active member of a learning community.

\section{ICT competencies for teachers}

Included among the skills necessary to be able to work and live successfully in the 21 st century society, ICT competencies are one of the latest additions to the requirements of teachers' education. And it is just fair. How to prepare students for a technological world, if the ones in charge of that responsibility are not prepared themselves? How could we justify ignoring in the classroom the practices and developments that are so common outside it?

For teachers, technologies are tools to rise above the school walls and bring into the class experiences that would not be possible otherwise: Virtual visits to museums and cities, digital visual dictionaries, simulations of physical and chemical processes, augmented reality for interacting digitally with objects... there are great learning opportunities in the use of digital technologies. 
Besides, digital technologies and particularly social media allow for configuring personal learning networks in which students and teachers can connect directly with experts from all around the world, attend virtual seminars or webinars and continue growing professonaly, academically and personally by establishing relationships with other with similar interests. The possibilities for learning are huge.

In the case of language teachers, technologies invite into the classroom a variety of cultures and accents, and the possibility of interacting with native speakers or with other learners from different countries. Music, films, TV channels, newspapers or catalogues: Internet provides us with an immense range of real materials, resources and apps for the English language class ${ }^{5}$. However, as expert in technology and language teaching Nik Peachy (2017) declares, the English language classroom is one of the spaces where we do not see as much change as one would expect. Although we have substituted some devices for others, the activities we do are rather similar to what we used to. Students, however, have changed. We see that now most of them come with some type of digital device they use to take notes, capture slides while the professors explain, access information and share it, together with their experiences through what Peachey (2017, para. 3) calls «their parallel digital reality» composed by a range of different apps and social media platforms.

The educational world cannot keep ignoring this reality. As educators, we need to find the way of integrating the use of technologies in the curriculum, in such a way that they are not a mere addition but a fundamental element in the development of our students's capacities for participating reflectively and with responsibility as future citizens and professionals of the 21st century. Doing that requires teachers who are updated not only in the new technological developments but also in the pedagogical and didactic approaches that allow to make the most of them in the classroom. As the UNESCO explains, «The successful integration of ICT into the classroom will depend on the ability of teachers to structure the learning environment in new ways, to merge new technology with a new pedagogy, to develop socially active classrooms, encouraging co-operative interaction, collaborative learning and group work» (2011, p.8).

This view is shared by the Colombian Ministry of Education since it includes ICT competencies among both the General and the Didactic Foundations that teacher training programs must include. Following this lead, the B.A. in Bilingual Education: English-Spanish of the Universidad Tecnològica de Pereira includes in its curriculum three subjects in which students develop their ICT competences, moving from basic ICT literacy into the understanding of the role of technologies in the educational processes, both face to face and online and the new roles that technologies demand from teachers and students.

The project that I will present next was designed with the purpose of helping students from the first semester of the B.A. in Bilingual Education: English-Spanish of the Universidad Tecnológica de Pereira to develop 21st century skills as well as research and ICT competences. It also intended to give them a first-hand experience of the PBL methodology, so they have the opportunity of understanding its advantages and challenges.

\section{Description of the Project}

As we have seen throughout this presentation, the development of 21 st century skills, research and ICT competences has become a necessity for future teachers in order to face the challenges of current education. PBL supported with ICT provides an ideal approach to achieve this purpose, since students are engaged in the search for information using different sources, the synthesis and elaboration of new products combining the information found and the use of a variety of digital tools and the communication of their results both to the group and to the world at large. 
With this aim, the students of the first semester of the B.A. in Bilingualism: English-Spanish from the Universidad Tecnológica de Pereira, are involved, during four weeks of the Computer Assisted Language Learning Course, in the development of a project that demands them to carry out an exploratory research about a topic of their choice, both in the internet and in the real world. The project requires the use of a variety of digital tools from the Google suite to collect, register and communicate the gathered information as well as a final presentation (to the group and the outside world), of the whole process, their findings and conclusions by an oral presentation in class and the elaboration of an infographic to be published in their blog. The project is completed with a self-reflection activity in which the students analyze and evaluate the process followed and the different types of learning achieved, as well as the difficulties they encountered throughout the activities.

The learners start the project by selecting a topic they want to explore. The choice of topics includes, but is not restricted to, the following areas: Academic themes (e.g., students' reading habits or how to balance studying and working), social issues (e.g., the use of social networks, gender equality, animal rights, etc.), or health and welfare problems (e.g. eating disorders or drug abuse). In short, any controversial or interesting topic they wish to explore.

In the first stage of the work, students, in pairs or groups of maximum 3 people, must explore the main idea of their topic in at least three different sources and get a definition for it and three or four interesting related facts. This stage of the project provides the opportunity for introducing Google Academic, as a more specific tool to search for scientific information. They must also use Google Docs to register the facts and definitions in a collaborative document. At this point, we take advantage of the task to explore how to reference and quote information coming from digital sources following APA style conventions.

The second stage of the project involves students in the creation of a survey to gather information about their topic. To start with, we observe surveys in the web and analyze the types of questions that they can employ: open-ended questions, multiple choice questions, multiple selection questions, interval scale questions, and questions for rating. We also go through the characteristics of good questions and comment about ethical issues as for example maintaining the privacy of responses, anonymity, etc. Although there are a number of websites where you can create an online survey as Jotform or Survey Monkey, we create the surveys in Google Forms, for a number of reasons. First, since it belongs to the Google Suite, we can access the app with the Google account we already used for creating the collaborative document. Besides, Google forms is very easy to use and can be inserted in a blog or web page by means of an embedding code. However, the most important feature is that it collects the results of your survey in a Google Sheets book (equivalent to an Excel file) and offers the user a summary of the responses with a basic analysis which includes the percentages obtained by the different answer options in each question. This summary of responses allows the students to get an overview of the results. At this step in the process, we review the different types of charts to illustrate the results: Pie charts, bar charts, lines and histograms.

With the information collected and analyzed, we move into the following stage. The groups of students have to create an infographic to communicate all the information they gathered, from the definitions and important facts, to the results of the survey they designed and applied and the conclusion they reached. The infographic is shared through their blog. We begin by exploring different infographics and analyzing the importance of both information and visual supporting elements, like images, colors and fonts of the text, use of icons and charts that help the reader understand the information presented in the infographic. Students are reminded about the importance of quoting and citing references appropriately, since this is a characteristic that gives value and reliability. 
Again, in this world of apps and websites, there are a number of options for creating infographics. We use Piktochart, because it allows to register with your Google account, it is simple to use and has great options for visual elements: from icons of every kind to videos or your own pictures if you wish to upload them. The management of numeric data is particularly interesting, with responsive charts which show values when you pass your mouse over them and whose icons can be customized.

This stage allows us to explore linguistic expressions to present the information and describe the charts and graphics (e.g., «is as big as», «it is twice as big as», «The bar chart presents...», «only one third ...», and «less than half ...»). We also discuss how the way in which information is presented modifies the perspective we are adopting. When facing a figure such as $40 \%$, describing it as «Almost half the interviewees ...» causes a different impression than if we say «Not even half the interviewees...» The glass can be seen as half full or half empty.

After receiving individual feedback on their products, students perform a five-minute oral presentation in which each group shares their infographic with the rest of the class. To support them in this last task, they receive input related to oral presentations: How to introduce their topic, how to indicate the end of a section and move to the next point or how to make an effective conclusion.

The project is completed with a final reflection activity, where students, individually, have to analyze and evaluate their learning process, their achievements, their difficulties, their role in the group and the experience from beginning to end.

Every stage of the process combines and demands the $4 \mathrm{C}$ 's in a research path: Collaboration in the process of looking for information and in the decisions about what to do and how to do it; Critical thinking for selecting an interesting topic, finding and discovering information, analyzing and interpreting the results; for reasoning and presenting arguments and conclusions; Creativity in the design of their infographic and the presentation of the information and Communication using digital media to deliver their findings, face-to-face to the group, and to the world through their blog.

\section{To sum up}

Innovative teaching practices are necessary if we want to educate future citizens and teachers with the competencies necessary for facing the changing challenges of the 21 st century. In this scenario, technology can be the best ally for Education, allowing and facitiliting more collaborative, creative and autonomous learning processes in which students can pursue their own interests at the time that they develop personal, academic and professional skills.

It is of the utmost importance that future English teachers are equipped with experiences and competencies that will allow them to develop innovative teaching practices, based on the evidence from the observation of their own classrooms and in which the use of technologies facilitates «knowledge deepening and knowledge creation» (Unesco, 2011, p.8). PBL can be one of the most appropriate approaches to achieve these purposes and the effort needed for designing attractive projects for the students, will be undoubtedly returned by the motivation and interest that they awake in students and the results they show.

\section{Notes}

${ }^{1}$ Data taken from Expansión.Datos macro. https://www.datosmacro.com/paro/espana?dr=2017-06

${ }^{2}$ Northamerican advocacy organization composed by educational institutions, teachers, education experts, and business leaders.

${ }^{3}$ https://www.youtube.com/watch?v=SU-yq_IJhtU

${ }^{4}$ https://zapatopi.net/treeoctopus/ 
${ }_{5}^{5}$ The Horizon Report (The New Media Consortium, https://www.nmc.org/publication/nmc-horizonreport-2017-higher-education-edition/) and the compilation presented yearly in the website 200 tools for learning (Centre for Learning and Performance Technologies, C4LPT,http://c4lpt.co.uk/ top100tools/) are very useful resources for teachers to be updated in the latest developments in the field of educational technology.

\section{References}

Andersen, E., (2014). How Google picks up their employees. (Hint: it's not about your degree). Forbes. Available at https://www.forbes.com/sites/erikaandersen/2014/04/07/how-googlepicks-new-employees-hint-its-not-about-your-degree/\#60ea1bb25e4d

Critical Thinking Foundation, (2015).Our Concept and Definition of Critical Thinking. Retrieved from http://www.criticalthinking.org/pages/our-concept-and-definition-of-critical-thinking/411

Hutchins, P., Huber, M. T., and Ciccone, A. (2011). The Scholarship of Teaching and Learning Reconsidered: Institutional Integration and Impact. San Francisco. Jossey-Bass.

Ministerio de Educación Nacional, (2009). Decreto 1290 de 2009. Retrieved from http://www. mineducacion.gov.co/1621/articles-187765_archivo_pdf_decreto_1290.pdf

Newton, P. M. (2015). The Learning Styles Myth is Thriving in Higher Education. Frontiers in Psychology, 6, 1908. http://doi.org/10.3389/fpsyg.2015.01908

OECD (1996). The knowledge-based economy. Paris. Retrieved from https://www.oecd.org/sti/scitech/1913021.pdf

Oxford University Press (2017). Word of the year 2016 is... Retrieved from https://en.oxforddictionaries. com/word-of-the-year/word-of-the-year-2016

Partnership for 21 st century learning (2007) Framework for21st Century Learning Retrieved from http://www.p21.org/our-work/p21-framework

Peachey, N. (2017) Digital skills that teachers need for the connected classroom \#1: Backchannels. [Blog post]. Retrieved from http://www.cambridge.org/elt/blog/2017/07/26/digital-skills-thatteachers-need-backchannels/

Rapacon, S. (2016, April 27). Career change is the new normal of working. CNBC News. Retrieved from https://www.cnbc.com/2016/04/26/career-change-is-the-new-normal-of-working.html

Robinson, K. (2015). Creativity is in everything, especially teaching. Retrieved from https://ww2. kqed.org/mindshift/2015/04/22/sir-ken-robinson-creativity-is-in-everything-especiallyteaching/

Robinson, V. (2003). Teachers as researchers: a professional necessity? Society for Education and Training, 1: 27-29. Retrieved from https:/set.et-foundation.co.uk/digital-assets/qtlsmap/ Resources/2/Teachers\%20as\%20Researchers\%20-\%20a\%20professional\%20necessity.pdf

Somekh, B. (2008). Action research in the Lisa M. Given (Ed), The SAGE Encyclopedia of Qualitative Research Methods (pp 4-7). California: Sage.

The Brainwaves Video Anthology (2014, March 2) Donald J. Leu - New Literacies Research Lab [Video file] Retrieved from https://www.youtube.com/watch? $=\mathrm{v}=\mathrm{zFN} 81 \mathrm{JAugDo}$.

Trelease, J. (2013). The read aloud handbook. Seventh Edition.Penguin: USA.

UNESCO (2011) ICT Competency Framework for Teachers. Retrieved from http://unesdoc.unesco. org/images/0021/002134/213475E.pdf

Winter, T. (2015). L\&D Neuromyth: Learning Styles (Visual, Auditory, Kinesthetic). [Blog post]. Retrieved from https://www.td.org/Publications/Blogs/Science-of-Learning-Blog/2015/07/ LD-Neuromyth-Learnin. 